\title{
QKI wt Allele
}

National Cancer Institute

\section{Source}

National Cancer Institute. QKI wt Allele. NCI Thesaurus. Code C111938.

Human QKI wild-type allele is located in the vicinity of $6 \mathrm{q} 26$ and is approximately $165 \mathrm{~kb}$ in length. This allele, which encodes protein quaking, plays a role in mRNA biosynthesis, mRNA splicing, mRNA stabilization, oligodendrocyte differentiation and myelination. A fusion of this gene and the NTRK2 gene may be associated with non-cerebellar pilocytic astrocytoma. 